\title{
Pediatric Sepsis: Genetic Considerations
}

\author{
N. Elek ${ }^{1}$ S. Sandor ${ }^{2} \quad$ G. Balazs ${ }^{3} \quad$ P. Dahlem ${ }^{2}$ \\ ${ }^{1}$ Department of Pediatrics, University of Debrecen, Debrecen, \\ Hungary \\ ${ }^{2}$ Department of Pediatrics, Medical Center Coburg, Academic \\ Hospital of the University of Split, Coburg, Germany \\ ${ }^{3}$ Clinical Center, Institute of Pediatrics, University of Debrecen, \\ Debrecen, Hungary
}

J Child Sci 2017;7:e76-e88.

\begin{abstract}
Address for correspondence N. Elek, MD, Department of Pediatrics University of Debrecen, Nagyerdei Krt. 98., H-4012 Debrecen, Hungary (e-mail: norbi81@gmail.com).
\end{abstract}

\begin{abstract}
Keywords

- sepsis

- infection

- genetics

- childhood

- polymorphism

- single-nucleotide polymorphism

- review

- systemic inflammatory response syndrome

The mortality of childhood sepsis continues to be rather high. When it comes to prevention and adequate therapy, individual differences and genetic alterations are becoming more and more important. These may affect molecules involved in pathogen recognition (e.g., lipopolysaccharide-binding protein, mannose-binding lectin, bactericidal/permeability-increasing protein, Toll-like receptors), signal transduction pathways (e.g., cRel), proinflammatory (e.g., tumor necrosis factor- $\alpha$, interleukin-1 [IL-1], IL-6, IL-8) as well as anti-inflammatory cytokines (e.g., IL-4, IL-10, IL-1 receptor antagonist), members of the coagulation cascade, and other molecules active in the process of systemic inflammatory response syndrome (e.g., heat shock proteins, complement system). The most common genetic polymorphisms are the so-called single-nucleotide polymorphisms, which entail the change of a single base. Genetic mutations have an impact on susceptibility, severity, and outcome of sepsis. Understanding such mutations may improve treatment efficiency; although there is a considerably limited choice of causal treatments today, they may become available upon future developments in genetic therapy.
\end{abstract}

\section{Introduction}

In addition to several other factors (e.g., type and virulence of pathogen, general condition of host, immune status), a substantial role is attributed to genetic factors in the development of pediatric sepsis. Several studies have found an association between changes in genes encoding systemic inflammatory response syndrome (SIRS) mediators and sepsis outcome. Some genetic variants can cause structural changes in proteins or changes in the amount of protein produced. Most commonly, this variability only affects a single nucleotide (single-nucleotide polymorphism, SNP). Genetic variants influence the body's susceptibility to the development of sepsis and modify the processes of normal systemic inflammatory response, impairing, or, on the contrary, improving disease outcomes. During SIRS, various causal factors (e.g., trauma, inflammation, infection) trigger the synthesis of proinflammatory, for example, tumor necrosis factor- $\alpha$ (TNF- $\alpha$ ), interleukin (IL)-1, IL-6, IL-8, and complement factors C3 and C5, as well as anti-inflammatory cytokines, for example, IL-4 and IL-10. Interestingly, genetic changes in components of the coagulation cascade influence the prognosis of sepsis and may affect molecules involved in pathogen recognition, pro- and anti-inflammatory cytokines, and other effector proteins (-Table $\mathbf{1}$ ). received

February 22, 2017 accepted after revision April 5, 2017
Issue Theme Pediatric Sepsis Biomarkers; Guest Editors: Peter Dahlem, MD, PhD, Marijan Saraga, MD, PhD, Prof. Walter L. Strohmaier, MD, PhD

DOI https://doi.org/ 10.1055/s-0037-1603803. ISSN 2474-5871.
Copyright @ 2017 Georg Thieme Verlag KG Stuttgart · New York

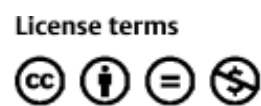




\section{Molecules Involved In Pathogen Recognition}

\section{Lipopolysaccharide-Binding Protein}

Lipopolysaccharide-binding protein (LBP) plays an important role in pathogen recognition and hence in triggering the immune response. First binding to gram-negative bacterial lipopolysaccharide (LPS) to form a complex, LBP is then bound to Toll-like receptor (TLR)-4/CD14/MD2 receptors of macrophages, thereby activating these immunocytes. ${ }^{1,2} \mathrm{~A}$ total of 112 SNPs have been identified in the LBP gene, the most important being rs2232618 (T1412C, Phe436Leu). A study conducted in a Chinese population has found that this SNP increases sepsis and multiple organ failure (MOF) incidence rates in relatively severe posttraumatic patients. ${ }^{3}$ Although the study involved an adult population, it is presumable that similar findings would be obtained in pediatric subjects.

\section{Bactericidal/Permeability-Increasing Protein}

Bactericidal/permeability-increasing protein (BPI) is primarily found in azurophilic granules of neutrophil granulocytes, but also detectable on the cellular surface and in specific granules of eosinophil granulocytes. ${ }^{4}$ It has a role in the defense against gram-negative bacteria by damaging external and internal bacterial membranes and neutralizing LPS, and, on the other hand, playing a part in opsonization. ${ }^{5-7}$ Two frequent polymorphisms have been identified, including the mutation known as BPI Taq (G545C), a so-called silent mutation since causing no change to the encoded amino acid (Val182) ${ }^{8}$ It has, however, been found to be associated with sepsis outcome in children, leading to a hypothesis that it may be a marker of other, hitherto unknown functional variants with which it is in a strong linkage disequilibrium. The homozygous GG allele was present in $85 \%$ of children with septic shock. No such association is currently known for the other SNP, BPI 216 (A645G, Lys216Glu). ${ }^{9}$

\section{NOD2/CARD15}

The NOD2 molecule recognizes bacterial particles (e.g., peptidoglycans) and stimulates immune response. ${ }^{10}$ Its most important polymorphism is the Leu1007fsinsC mutation, which causes the produced protein to be unable to activate the nuclear factor $\mathrm{KB}(\mathrm{NF}-\mathrm{KB})$ molecule. ${ }^{11}$ This leads to a slowdown of monocytic phagocytosis, which contributes to the development of bacteremia and sepsis.

\section{Toll-like Receptors}

TLRs constitute a part of the innate immune system. To date, as many as 11 types have been described. ${ }^{12}$ They recognize what is referred to as "pathogen-associated molecular patterns." ${ }^{13}$ TLR signal pathways elicit the activation of common transcription factors (NF-KB and mitogen-activated protein kinases [MAPKs]) and result in the production of cytokines IL-6, IL-10, and IL-12, as well as the costimulatory molecules CD40 and B7. However, although various TLRs bring similar or identical molecules (MyD88, NF-KB) into action during their activation, they can elicit immune responses that are different and unique to a single TLR type.

\section{Toll-like Receptor 1}

TLR-1 is found in membranes of macrophages, dendritic cells, eosinophils, basophils, and mast cells, forming a heterodimer with TLR-2. Of the two most common SNPs of the TLR-1 gene, TLR1-7202A/G (Asn248Ser), which is found in the 5' nontranscribed region of the TLR gene, shows a stronger association with clinical outcome than TLR1 $1_{1804 G / T}$ (Ser602Ile), which encodes a protein located in the transmembrane domain. ${ }^{14}$ TLR1_-7202G is a hypermorphic allele strongly associated with sepsis-related organ damage and mortality in the American population. ${ }^{15}$ Increased receptor density on the cellular surface owing to the mutation is thought to be responsible for this effect. In the presence of the TLR $1_{1804 \mathrm{~T}}$ (602lle) allele, NF-KB induction is intensified in Staphylococcus aureus infection. ${ }^{16}$ With another SNP, TLR1 $1_{1805 \mathrm{G} / \mathrm{T}}$, when the $\mathrm{T}$ allele was present in a homozygous form, intensive care unit length of stay significantly increased in septic children whose blood cultures were positive. Compared with G/G homozygous patients, length of stay was also longer in $\mathrm{G} / \mathrm{T}$ heterozygous cases, which is explained by an increase in neutrophil activation rates when the $\mathrm{T}$ allele is present. ${ }^{17}$

\section{Toll-like Receptor 2}

TLR-2 is the most important member of the receptor family, having a role in the recognition of various bacterial lipoproteins. ${ }^{18}$ Several studies have proven that TLR-2 has a fundamental role in antibacterial defense. The TLR-2 gene's best known polymorphism is TLR-2 Arg753Gln, which inhibits tyrosine phosphorylation, dimer formation with TLR6, and the buildup of MyD88, and affects NF-кB activation. ${ }^{19,20}$ Consequently, peptidoglycan- and lipopeptide-triggered intracellular signal transduction and cytokine secretion are compromised, leading to a weakened immune response, which may result in the onset of severe sepsis. ${ }^{21}$ Although a study on a smaller group of Asian adults detected no clear association, and no major pediatric studies were completed so far, it is presumed that findings similar to those in adults would be obtained in children. The role in sepsis of another polymorphism, TLR2 Arg677Trp, has not been investigated, but it is clear that this predisposes children to infections caused by S. aureus and other pathogens.

\section{Toll-like Receptor 4}

As part of the innate immune system, TLR-4 plays an important role in the defense against gram-negative bacteria, but it also recognizes mycobacterial and fungal proteins, as well as being activated by endogenous ligands. Compounds synthesized due to the signal transduction process triggered by TLR- 4 include TNF- $\alpha$, IL- $1 \beta$, and interferon- $\beta$ (IFN- $\beta$ ), among others. There are two polymorphisms known to affect receptor function, Asp299Gly (rs4986790) and Thr399Ile (rs4986791), which cause cytokine synthesis rates to drop, with a consequential increase in susceptibility to gramnegative bacteria. ${ }^{22}$ Results concerning a link between these SNPs and sepsis are controversial; haplotype Asp299Gly/ Asp299Gly seems to induce enhanced TNF- $\alpha$ synthesis in response to LPS, thus predisposing to sepsis development, whereas haplotype Asp299Gly/Thr399Ile has no or limited 
Table 1 The most important genetic polymorphisms in sepsis

\begin{tabular}{|c|c|c|c|}
\hline Gene & Polymorphism & Consequence & References \\
\hline$\angle B P$ & $\begin{array}{l}\text { rs2232618 (T1412C, } \\
\text { Phe436lle) }\end{array}$ & $\begin{array}{l}\text { Increases sepsis and MOF incidence rates in relatively severe posttrau- } \\
\text { matic patient }\end{array}$ & 3 \\
\hline$B P I$ & Taq (G545C) & The GG allele associates with sepsis outcome in children & 9 \\
\hline NOD2/CARD15 & Leu1007fsinsC & The produced protein unable to activate the NF-kB & 11 \\
\hline \multirow[t]{2}{*}{$T L R-1$} & $-7202 \mathrm{~A} / \mathrm{G}$ (Asn248Ser) & Strongly associated with sepsis-related organ damage and mortality & 15 \\
\hline & $1805 \mathrm{G} / \mathrm{T}$ & $\begin{array}{l}\text { The TT allele increases the intensive care unit length of stay in septic } \\
\text { children }\end{array}$ & 17 \\
\hline \multirow[t]{2}{*}{$T L R-2$} & Arg753Gln & $\begin{array}{l}\text { Inhibits tyrosine phosphorylation, dimer formation with TLR- } 6 \text {, and the } \\
\text { buildup of MyD88, and affects NF-KB activation }\end{array}$ & 19,20 \\
\hline & Arg677Trp & Predisposes children to infections caused by Staphylococcus aureus & \\
\hline \multirow[t]{3}{*}{$T L R-4$} & $\begin{array}{l}\text { rs4986790 } \\
\text { (Asp299Gly); } \\
\text { rs4986791 } \\
\text { (Thr399lle) }\end{array}$ & $\begin{array}{l}\text { Cause cytokine synthesis rates to drop, with a consequential increase in } \\
\text { susceptibility to gram-negative bacteria }\end{array}$ & 22 \\
\hline & $\begin{array}{l}\text { haplotype Asp299Gly/ } \\
\text { Asp299Gly }\end{array}$ & $\begin{array}{l}\text { Induces enhanced TNF- } \alpha \text { synthesis in response to LPS, predisposes to } \\
\text { sepsis development }\end{array}$ & $23-25$ \\
\hline & rs1927907 & Plays a role in the development of $S$. aureus sepsis & 26,27 \\
\hline CD14 & rs2569190 (-159C/T) & Leads to increased CD14 levels & 32 \\
\hline$M B L$ & $B, C, D$ variants & Causes the protein's serum levels to drop & $35-38$ \\
\hline cRel & $\begin{array}{l}\text { rs842647 } \\
\text { (A61119471G), } \\
\text { rs13031237 } \\
(\mathrm{G} 61136129 \mathrm{~T})\end{array}$ & rs $842647^{*} \mathrm{G}$ increases the risk of MOF in septic patients & 40 \\
\hline$T N F-\alpha$ & $-308 \mathrm{G} / \mathrm{A}$ & $\begin{array}{l}\text { TNF2 (A) allele increases TNF- } \alpha \text { secretion and mainly affects sepsis onset } \\
\text { risks rather than outcomes }\end{array}$ & $43-45$ \\
\hline TNF- $\beta$ & $\begin{array}{l}\text { TNFB1, } \\
\text { TNFB2 }\end{array}$ & $\begin{array}{l}\text { TNFB1 causes elevated serum levels, and hence increased mortality, in } \\
\text { septic children }\end{array}$ & 47 \\
\hline IL-1 $\alpha$ & $-889 \mathrm{C} / \mathrm{T}$ & $\begin{array}{l}\text { Causes elevated IL- } 1 \alpha \text { expression, which some studies describe as being } \\
\text { associated with sepsis }\end{array}$ & 52 \\
\hline \multirow[t]{3}{*}{ IL-1 } & $+3954 C / T$ & $\begin{array}{l}\text { Changes splice donor site, leading to the synthesis of fragile, inactive } \\
\text { molecules; the T allele increases IL-1 } \beta \text { production induced by LPS; the } \\
\text { presence of TT alleles carries a reduced risk of sepsis }\end{array}$ & \multirow[t]{3}{*}{$52-54$} \\
\hline & $-511 G / A$ & Elevates IL-1 $\beta$ levels in response to endotoxins & \\
\hline & $-31 C / T$ & Affects transcription factor binding sites, hence transcription activity & \\
\hline \multirow[t]{2}{*}{ IL-6 } & $-174 G / C$ & $\begin{array}{l}\text { The } C \text { allele is associated with lower plasma levels; the } \mathrm{G} \text { allele seems to } \\
\text { be protective against sepsis }\end{array}$ & 62,63 \\
\hline & $\begin{array}{l}\text { Haplotype variants } \\
(-174 / 1753 / 2954)\end{array}$ & Increase mortality or MOF & 64 \\
\hline \multirow[t]{3}{*}{ IL-8 } & $-251 \mathrm{~T} / \mathrm{A}(\mathrm{rs} 4073)$ & $\begin{array}{l}\text { Significantly increases the risk of severe sepsis in newborns; the T allele is } \\
\text { protective against sepsis in women }\end{array}$ & 66 \\
\hline & rs1126647 & The $\mathrm{A}$ allele is protective against sepsis in women & \multirow[t]{2}{*}{70} \\
\hline & rs2227306 & The $C$ allele represents an elevated risk of sepsis in men & \\
\hline \multirow[t]{3}{*}{ IFN- $\gamma$} & $-1616 \mathrm{~T} / \mathrm{C}(\mathrm{rs} 2069705)$ & The $T$ allele has a protective effect against sepsis development & \multirow[t]{3}{*}{72} \\
\hline & $\begin{array}{l}+3234 C / T \\
(r s 2069718)\end{array}$ & The $C$ allele protects from severe sepsis & \\
\hline & $\begin{array}{l}-1616 /-764 /+874 \\
\text { haplotype }\end{array}$ & $\begin{array}{l}\text { The CTT haplotype is protective against sepsis; TAC haplotype is } \\
\text { associated with susceptibility to sepsis and protects against severe sepsis }\end{array}$ & \\
\hline \multirow[t]{3}{*}{ HMGB1 } & 1377delA & Significantly makes worsen late-phase sepsis mortality & \multirow[t]{2}{*}{76} \\
\hline & $982 \mathrm{C} / \mathrm{T}$ & Increases early mortality risk in sepsis & \\
\hline & rs1045411 (2262G/A) & $\begin{array}{l}\text { The } A \text { allele causes far more severe inflammatory response than the GG } \\
\text { genotype }\end{array}$ & 77 \\
\hline
\end{tabular}


Table 1 (Continued)

\begin{tabular}{|c|c|c|c|}
\hline Gene & Polymorphism & Consequence & References \\
\hline IL-1RA & 86 base-pair-long VNTR & $\begin{array}{l}\text { The A2 allele causes elevated IL-1 } \alpha \text {, and even higher IL-1 } 1 \beta \text { levels; the } \\
\text { resulting lower IL-1 } \alpha: I L-1 \beta \text { ratio leads to more intensified and lengthier } \\
\text { inflammatory response and also results in reduced IL-1RA levels in } \\
\text { severely septic patients }\end{array}$ & $79-81$ \\
\hline IL-10 & $-1082(\mathrm{~A} / \mathrm{G})$ & $\begin{array}{l}\text { The } A \text { allele is associated with susceptibility to sepsis, whereas the } G \text { allele } \\
\text { causes enhanced IL-10 production and increases mortality in severe } \\
\text { sepsis }\end{array}$ & 83,84 \\
\hline$P C$ & $\begin{array}{l}(-1654 \mathrm{C} / \mathrm{T},-1641 \mathrm{~A} / \mathrm{G}) \\
\text { single haplotype }\end{array}$ & $\begin{array}{l}\text { The homozygous GC genotype is associated with significantly lower PC } \\
\text { levels increasing the propensity to thrombosis in sepsis; it also worsens } \\
\text { outcomes by causing hypotension } \\
\text { The homozygous TA genotype has a protective effect on sepsis out- } \\
\text { comes } \\
\text { The genotype - } 1641 \mathrm{~A} / \mathrm{A} \text {, worsens survival and aggravates systemic } \\
\text { inflammation }\end{array}$ & $89-91$ \\
\hline PAl-1 & $\begin{array}{l}-6754 \mathrm{G} / 5 \mathrm{G} \text { insertion/ } \\
\text { deletion }\end{array}$ & $\begin{array}{l}\text { The 4G/4G genotype results in elevated plasma levels and activity and } \\
\text { increases susceptibility to sepsis and mortality in children with menin- } \\
\text { gococcal infection, as well as raises the incidence of DIC }\end{array}$ & 93,94 \\
\hline Fibrinogen & $\begin{array}{l}-854 \mathrm{G} / \mathrm{A} \\
-455 \mathrm{G} / \mathrm{A} \\
+9006 \mathrm{G} / \mathrm{A}\end{array}$ & $\begin{array}{l}\text { The GAA haplotype causes elevated fibrinogen levels owing to the } \\
-455 \mathrm{~A} \text { allele, yet it reduces mortality and MOF incidence in sepsis }\end{array}$ & $100-103$ \\
\hline FcyRlla & $\mathrm{R} 131 \mathrm{H}$ & $\begin{array}{l}\text { The R131 allotype causes the receptor to bind the IgG2 molecule with a } \\
\text { reduced affinity, which results in a slowdown of IgC2-opsonized } \\
\text { phagocytosis }\end{array}$ & $110-112$ \\
\hline FcyRIIIa & Val158Phe & Modifies the receptor's affinity to $\lg G 1, \lg G 2$, and $\lg G 4$ & 116,117 \\
\hline FcyRIIIb & $\begin{array}{l}\text { switch in four amino } \\
\text { acids ( } \mathrm{Na} 1 / \mathrm{Na} 2 \text { ), }\end{array}$ & $\begin{array}{l}\text { Affects the extracellular domain and has a role in protein glycosylation } \\
\text { and hence the phagocytosis of particles opsonized by } \lg \mathrm{G} 1 \text { and } \lg \mathrm{G} 3\end{array}$ & $118-120$ \\
\hline \multirow[t]{2}{*}{$\mathrm{CFH}$} & $\mathrm{Y} 402 \mathrm{H}$ & $\begin{array}{l}\text { Has a protective effect because inhibition of the alternative pathway } \\
\text { becomes muted and has a higher baseline level of activity }\end{array}$ & 131 \\
\hline & $-496 C / T$ & $\begin{array}{l}\text { The CC genotype, accompanied by elevated CFH levels, is a factor of } \\
\text { increased risk for meningococcal infection }\end{array}$ & 132 \\
\hline MIF & $\begin{array}{l}-173 \mathrm{G} / \mathrm{C}(\mathrm{rs} 755622) \\
-794 \mathrm{CATT}_{5-8} \\
(\text { rs5844572) }\end{array}$ & $\begin{array}{l}\text { CATT7/8 is associated with severely complicated malaria, mortality of } \\
\text { severely septic patients, and survival in community-acquired pneumonia } \\
\text { The low-expression allele (CATT5) has a protective effect against me- } \\
\text { ningococcal infection in children } \\
\text { Haplotype }-173 C /-794 \text { CATT7 may help identify patients at increased } \\
\text { risk of sepsis mortality }\end{array}$ & $137-139,143$ \\
\hline \multirow[t]{2}{*}{ HSPA1A } & rs1008438 & The $\mathrm{A}$ allele causes hematological impairment & \multirow[t]{2}{*}{147} \\
\hline & rs1043618 & $\begin{array}{l}\text { The } C \text { allele leads to longer intensive care unit treatment periods in } \mathrm{H} 1 \mathrm{~N} 1 \\
\text { infection and to a higher incidence of liver failure and MOF in severe } \\
\text { trauma cases }\end{array}$ & \\
\hline \multirow[t]{2}{*}{ HSPA1B } & $1538 \mathrm{G} / \mathrm{A}$ & The $A$ allele causes elevated TNF- $\alpha$ and IL- 6 levels & 146 \\
\hline & $\begin{array}{l}1267 A>G \\
(r s 1061581)\end{array}$ & $\begin{array}{l}\text { Increases the risk of sepsis in adults with community-acquired pneu- } \\
\text { monia } \\
\text { The AA genotype is clearly associated with sepsis secondary to com- } \\
\text { munity-acquired pneumonia } \\
\text { The A allele causes hematological impairment }\end{array}$ & 147,148 \\
\hline HSPA1L & $\begin{array}{l}2437 C>T \\
(r s 2227956)\end{array}$ & $\begin{array}{l}\text { The C allele causes elevated TNF- } \alpha \text { and IL- } 6 \text { levels and is also a significant } \\
\text { risk factor for liver failure and MOF }\end{array}$ & 146 \\
\hline HSP70-2 & HSP70-2A/G & $\begin{array}{l}\text { The } G \text { allele is associated with lower protein levels and represents an } \\
\text { increased risk for sepsis } \\
\text { The A allele, a link has been found with TNF- } \beta 2 \text {, which worsens outcomes } \\
\text { in sepsis }\end{array}$ & 149 \\
\hline DDAH2 & $-449 G / C$ & $\begin{array}{l}\text { The -449G allele has been shown to result in lower ADMA levels and is } \\
\text { more likely to be present in sepsis accompanied by "cold shock" }\end{array}$ & 156 \\
\hline
\end{tabular}

Abbreviations: ADMA, asymmetric dimethylarginine; BPI, bactericidal/permeability-increasing protein; $\mathrm{CFH}$, complement factor $\mathrm{H}$; DDAH, dimethylarginine dimethylaminohydrolase; DIC, disseminated intravascular coagulation; HMGB1, high mobility group box 1; IFN-y, interferon gamma; IgG, immunoglobulin G; IL, interleukin; IL-1RA, interleukin-1 receptor antagonist; LBP, lipopolysaccharide-binding protein; LPS, lipopolysaccharide; MBL, mannose-binding lectin; MIF, macrophage migration inhibitory factor; MOF, multiple organ failure; NF-kB, nuclear factor KB; PAI-1, plasminogen activator inhibitor 1; PC, protein C; TLR, Toll-like receptor; TNF, tumor necrosis factor; VNTR, variable number of tandem repeats. 
effect on receptor function. ${ }^{23-25}$ Selected studies conclude that rs1927907 polymorphism plays a role in the development of $S$. aureus sepsis; in this case, the receptor is activated by substances other than LPS, indicating that TLR-4 probably also responds to endogenous ligands. ${ }^{26,27}$

\section{CD14}

The CD14 protein has an important role in the recognition of gram-negative bacteria since it activates the NF-кB pathway by binding to TLR4 as part of the LPS-CD14-MD2 complex. ${ }^{1}$ CD14 is found on the surface of monocytes, macrophages, and neutrophil granulocytes in a membrane-linked form, but a soluble form also exists. ${ }^{28}$ Elevated CD14 levels pose an increased risk to sepsis and MOF. ${ }^{29,30}$ Many polymorphisms of the gene are known; the most commonly described mutation being rs $2569190(-159 \mathrm{C} / \mathrm{T})$ in the promoter region, leading to increased CD14levels. ${ }^{31}$ Its association with sepsis is controversial; although several studies have reported about a link between this polymorphism and sepsis, mainly in the Asian population, but further studies are needed for a clear standpoint in this issue. ${ }^{32}$

\section{Mannose-Binding Lectin}

Mannose-binding lectin (MBL) is a selectin molecule, which, by binding to mannose and bacterial $\mathrm{N}$-acetyl galactosamine components, activates the complement system through the lectin pathway. ${ }^{33}$ There are three known polymorphisms of the $M B L-2$ gene at the codon 52, 54, and 57 (referred to as variants $B, C$, and $D$, respectively, or collectively as $O$, whereas the wild type denoted as $A$ ). The mutations cause an amino acid switch, which interferes with oligomerization, causing the protein's serum levels to drop. Patients with MBL deficiency are more susceptible to sepsis. MBL levels are lower in $\mathrm{A} / \mathrm{O}$ heterozygosis, whereas circulatory MBL is almost completely absent in $\mathrm{O} / \mathrm{O}$ homozygous or compound heterozygous cases. ${ }^{34}$ Added to these three mutations, there are three major polymorphisms in the promoter region, one of which $(-221 \mathrm{G} / \mathrm{C}$, also known as $\mathrm{Y} / \mathrm{X})$ is a major factor of $\mathrm{MBL}$ expression. ${ }^{35}$ The three polymorphisms in exon 1 are in linkage disequilibrium with the promoter $\mathrm{X} / \mathrm{Y}$ polymorphism, with $\mathrm{Y}$ being the only variant with a link to each. ${ }^{36,37}$

\section{Polymorphisms Affecting Signal Transduction Pathways}

\section{cRel Polymorphism}

The cRel protein is a subunit of NF- $\mathrm{kB}$. The latter is a protein complex with a central role in the body's response to infections. It is activated through two possible pathways. The canonical pathway involves TLR as well as proinflammatory cytokines (e.g., TNF- $\alpha$, IL-1) activating the RelA protein, which has proinflammatory effects and activates genes responsible for the cell's survival. ${ }^{38}$ The other one is an alternative pathway initiated by LTb, CD40L, BAFF, and RANKL, followed by activation of the RelB/p52 complex, resulting in transcription of genes responsible for lymph organogenesis and B-cell activation. There are two important polymorphisms of the cRel gene: rs842647 and rs13031237; the former one leading to an $A \rightarrow G$ substitution at location 61119471 in intron 2 , whereas the latter eliciting a $\mathrm{G} \rightarrow \mathrm{T}$ switch at location 61136129 , intron 4 , chromosome 2 . It has been shown that the minor allele $\mathrm{rs} 842647^{*} \mathrm{G}$ increases the risk of MOF in septic patients, whereas no association with the severity of septic shock has been found for the allele rs $13031237 * T^{39}$

\section{Proinflammatory Cytokines}

\section{Tumor Necrosis Factor- $\alpha$, Tumor Necrosis Factor Receptor}

TNF- $\alpha$ is a proinflammatory cytokine involved in the process of SIRS and in initiation of the acute phase reaction. Dominantly produced by activated macrophages, TNF- $\alpha$ can also be a product of CD4+ T-lymphocytes, neutrophils, mast cells, eosinophilic granulocytes, and neurons. Its primary function is immune cell regulation. Bound by either of two receptors, TNFR1 and TNFR2, TNF- $\alpha$ can then activate three pathways: NF-KB, MAPK, and the so-called cell-death pathway. Many SNPs at the TNF/LTA locus have been identified as affecting TNF- $\alpha$ production and being associated with sepsis onset or outcomes. ${ }^{40}$ The most commonly known mutation is $-308 \mathrm{G} /$ A; notable examples also include the polymorphisms $-238 \mathrm{G} /$ A and LTA $($ TNF- $\beta)+249$ and $+365 .{ }^{41}$ The TNF- $\alpha-308 G / A$ polymorphism affects the promoter region and causes one TNF1 (G) and one TNF2 (A) allele to be present, the latter leading to increased TNF- $\alpha$ secretion, a condition mainly affecting sepsis onset risks rather than outcomes. ${ }^{42-44}$ As for $-238 \mathrm{G} / \mathrm{A}$ SNP, the $-238 \mathrm{~A}$ allele results in reduced TNF- $\alpha$ levels. $^{45}$ The associated TNF- $\beta$ polymorphism entails a TNFB1 and a TNFB2 allele, with the latter causing elevated serum levels, and hence increased mortality, in septic children. $^{46}$

\section{Interleukin-1}

Members of the IL-1 family have an important role in inflammatory responses and the pathomechanism of sepsis. The family includes one anti-inflammatory and two proinflammatory (IL- $1 \alpha$ and IL-1 $\beta$ ) cytokines. ${ }^{47-49}$ The genes are in a cluster on the long arm of chromosome $2(2 q 13-21) .{ }^{50}$ A total of five SNPs that can be linked to sepsis are known in the IL-1 gene. These include $-889 \mathrm{C} / \mathrm{T}$ in the promoter region of the $I L-1 \alpha$ gene, $-511 \mathrm{G} / \mathrm{A}$ and $-31 \mathrm{C} / \mathrm{T}$ in the promoter region of the $I L-1 \beta$ gene, and $+3954 \mathrm{C} / \mathrm{T}$ in exon $5 .^{51}+3954 \mathrm{C} / \mathrm{T}$ polymorphism causes no amino acid switch, but changes splice donor site, leading to the synthesis of fragile, inactive molecules. ${ }^{52}$ The $\mathrm{T}$ allele increases IL-1 $\beta$ production induced by LPS. ${ }^{53}$ It has also been shown that the presence of TT alleles carries a reduced risk of sepsis; however, this is inconsistent with the observation that elevated IL-1 $\beta$ levels represent greater susceptibility to sepsis. Additional factors are presumed to be in the background of this controversy; further studies into the link between this polymorphism and sepsis are necessary. The IL- $1 \alpha-889 \mathrm{C} / \mathrm{T}$ mutation causes elevated IL- $1 \alpha$ expression, which some studies describe as being associated with sepsis. Although IL-1 $\beta-511 \mathrm{G} / \mathrm{A}$ elevates IL-1 $\beta$ levels in response to endotoxins, and IL-1 $\beta-31 \mathrm{C} / \mathrm{T}$ affects 
transcription factor binding sites and hence transcription activity, the link between these SNPs and sepsis remains controversial. $^{51}$

\section{Interleukin-6}

IL-6 is a proinflammatory cytokine playing an important role in evolvement of the inflammatory response. IL-6 gene polymorphisms may have a role in the development and outcomes of childhood sepsis. ${ }^{54,55}$ It has been reported that in the IL-6 - $174 \mathrm{G} / \mathrm{C}$ mutation, the $\mathrm{C}$ allele is associated with lower plasma levels; however, the results are unclear, with some researchers having found such relationship in newborns only, and other studies pointing out that plasma levels of IL-6 variants depend on sex, age, body mass index, and general health. ${ }^{56-59}$ An association with better survival has been detected in GG homozygous cases, and the G allele seems to be protective against sepsis. ${ }^{60,61}$ Moreover, reports also describe a link between haplotype variants (e.g., -174/ $1753 / 2954)$ and increased mortality or MOF. ${ }^{62}$ The other polymorphism is $-572 \mathrm{G} / \mathrm{C}$, where the $\mathrm{C}$ allele causes a similar deviation in plasma levels compared with the earlier polymorphism. ${ }^{59}$ However, the relationship of this variant with sepsis remains unknown.

\section{Interleukin-8}

IL-8, also known as neutrophil chemotactic factor, is a chemokine produced by macrophages, epithelial cells, airway smooth muscle cells, and endothelial cells. It has two primary functions including chemotaxis induction in neutrophil and other granulocytes, and having a role in phagocytosis induction and angiogenesis. Elevated IL-8 levels are associated with the development of severe sepsis. ${ }^{63}$ Baseline IL-8 level is one of the most important prognostic factors for sepsis outcome. ${ }^{64}$ There is a link between IL- 8 gene polymorphisms and sepsis onset; SNP IL-8 -251T/A (rs4073) has been described to significantly increase the risk of severe sepsis in newborns. ${ }^{65}$ The findings are controversial, with some studies identifying the T allele as causing elevated IL-8 levels and others claiming the same about the A allele even examples of a failure to detect a difference in IL-8 levels for the different alleles that exist. ${ }^{66-68}$ However, the T allele has been found to be protective against sepsis in women. The same was identified in rs1126647 mutation for the A allele. In both cases, a greater incidence of the protective allele was confirmed in women. As for the rs2227306 mutation, the $\mathrm{C}$ allele represented an elevated risk of sepsis in men. ${ }^{69}$

\section{Interferon Gamma}

INF gamma (IFN- $\gamma$ ) is a cytokine that is an important component of the innate and acquired immunity with a primary role in antiviral defense and an activity against selected bacterial and protozoal species. It is mainly produced by NK and NKT cells, but can also be synthesized by CD4+ Th1 and CD8+ cytotoxic T cells. IFN- $\gamma$ is an important activator of macrophages and induces major histocompatibility complex II (MHCII) expression. Its importance is rooted in its direct viral replication inhibitory capacity, as well as immunostimulant and immunomodulatory effects. ${ }^{70}$
Highlights of IFN-rgene polymorphisms include four entities with links to immunological pathologies. Two of these, -1616T/C (rs2069705) and -764G/C (rs2069707), are found in the promoter region, with another located in intron 1 $(+874 \mathrm{~A} / \mathrm{T}$ [rs2430561] $)$ and yet another in intron $3(+3234 \mathrm{C} /$ $\mathrm{T}$ [rs2069718]). Alleles -1616T, -764G, $+874 \mathrm{~A}$, and $+3234 \mathrm{C}$ have been shown to cause elevated IFN- $\gamma$ levels compared with their counterpart variants. Reports also indicate that the SNPs +874 and +3234 are in a "linkage disequilibrium" with each other. Studies have demonstrated that the -1616T allele has a protective effect against sepsis development and that the +3234 C allele protects from severe sepsis. Research into the haplotypes of $-1616,-764$, and +874 found that the CTT haplotype is protective against sepsis, but only minimally protective against the development of severe sepsis, whereas the TAC haplotype is associated with susceptibility to sepsis and protects against severe sepsis. The TAC haplotype comprises three alleles encoding enhanced gene expression and represents the most common combination, with CTT being the rarest. Patients whose IFN- $\gamma$ expression is enhanced have a greater propensity to develop sepsis but are at a lower risk of severe sepsis, whereas those with lower IFN- $\gamma$ expression rates are less prone to sepsis. ${ }^{71}$

\section{High Mobility Group Box 1}

High mobility group box 1 (HMGB1), also known as nuclear nonhistone DNA-binding protein, is a multifunctional cytokine with a role in late-phase inflammatory response. It is mainly produced by macrophages and monocytes in response to LPS through a TNF- $\alpha$-dependent mechanism, but it is also released by necrotic but not apoptotic cells, which is a way for the body to differentiate between these cells. $^{72,73}$ In addition to its cell-damaging effect, HMGB1 also has a protective function in that it elicits stem cell migration into inflamed areas, promoting regeneration. ${ }^{74}$ HMGB1 levels are significantly higher in septic patients, and in mice model, anti-HMGB1 antibodies significantly reduce mortality. ${ }^{73}$ The HMGB1 gene has many polymorphisms, two of which have a significance in sepsis; one such mutation is -1377delA, which has been shown to significantly worsen late-phase sepsis mortality. The other polymorphism is $982 \mathrm{C} / \mathrm{T}$, which is found in exon 4 and is associated with significantly lower HMGB1 levels than the homozygous 982C/C genotype, thereby increasing early mortality risk in sepsis. ${ }^{75}$ Research in Korean children has found that the A allele in rs1045411 (2262G/A) polymorphism causes far more severe inflammatory response than the GG genotype. ${ }^{76}$

\section{Anti-Inflammatory Cytokines}

\section{Interleukin-1 Receptor Antagonist}

As suggested by its name, the IL-1 receptor antagonist binds to the IL-1 receptor to inhibit its function. There is an 86base-pair long VNTR (variable number of tandem repeats) sequence in intron 2 of the IL- 1 receptor antagonist (IL-1RA) gene, involving five different alleles (1-5) of different repeat frequencies $(4,2,5,3$, and 6 repetitions). These are further 
classified into long ( $L: 1,3,4,5)$ and short (2 only) genotypes, with possible combinations including $\mathrm{L} / \mathrm{L}, \mathrm{L} / 2$, and $2 / 2 .{ }^{77}$ The A2 allele causes elevated IL- $1 \alpha$, and even higher IL- $1 \beta$ levels. The resulting lower IL- $1 \alpha:$ IL- $1 \beta$ ratio leads to more intensified and lengthier inflammatory response. ${ }^{78,79}$ This allele also results in reduced IL-1RA levels in severely septic patients. ${ }^{80}$ All this indicates that this polymorphism plays an important role in immune response regulation.

\section{Interleukin-10}

L-10, also known as "human cytokine synthesis inhibitory factor," is an anti-inflammatory cytokine with a central role in immunoregulation and inflammatory processes. Its functions include down-regulation of cytokines expressed by Th1 cells, moreover that of MHCII antigens and macrophageal costimulant molecules. ${ }^{81}$ It also promotes B-cell survival, proliferation, and antibody production. IL-10 inhibits NF-кB activity and has a role in regulation of the JAK-STAT signal pathway. Several IL-10 polymorphisms are known, of which SNP $-1082(\mathrm{~A} / \mathrm{G})$ in the promoter region has been linked to sepsis. The presence of the $\mathrm{A}$ allele is associated with susceptibility to sepsis, whereas that of the $G$ allele causes enhanced IL-10 production and increases mortality in severe sepsis. ${ }^{82,83}$ No such relationship has been found for the other two frequent polymorphisms (-592 and $-819) .{ }^{84}$

\section{Polymorphisms Affecting the Coagulation System}

The coagulation system is activated in sepsis in response to bacterial endotoxins, resulting in enhanced expression of tissue factor in monocytes and endothelial cells, thus activating the extrinsic pathway of the coagulation cascade. However, sepsis essentially leads to complex dysregulation of procoagulant, anticoagulant, and fibrinolytic proteins. The presence of various gene polymorphisms is also important in relation to the outcome of sepsis-related disseminated intravascular coagulation (DIC).

\section{Protein C}

Protein C (PC) is a vitamin $\mathrm{K}$ dependent zymogenic serine protease synthesized in the liver; once activated and bound to thrombomodulin, it inactivates factors Va and VIIIa in the presence of protein $\mathrm{S}, \mathrm{PL}$, and $\mathrm{Ca}^{2+}$, thereby blocking any further production of thrombin. It also has anti-inflammatory and antiapoptotic effects. ${ }^{85}$ Of the polymorphisms of the $P C$ gene, two located in the gene's $5^{\prime}$ nontranscribed region $(-1654 \mathrm{C}>\mathrm{T},-1641 \mathrm{~A}>\mathrm{G})$ bear importance. ${ }^{86,87}$ These two polymorphisms form a single haplotype where the homozygous GC genotype is associated with significantly lower PC levels, increasing the propensity to thrombosis in sepsis; it also worsens outcomes by causing hypotension. ${ }^{88}$ The homozygous TA genotype has a protective effect on sepsis outcomes because the higher PC levels decrease the incidence of DIC in sepsis, thereby improving survival. ${ }^{89}$ The genotype $-1641 \mathrm{~A} / \mathrm{A}$, however, worsens survival and aggravates systemic inflammation. ${ }^{90}$

\section{Plasminogen Activator Inhibitor 1}

The plasminogen activator inhibitor 1 (PAI-1) molecule is a serine protease inhibitor blocking tissue plasminogen activator (tPA) and urokinase plasminogen activator, the activators of plasminogen and hence fibrinolysis; it also forms a complex with activated PC (APC) to inhibit the latter's function. Based on this behavior, PAI-1 has a procoagulant effect. Several polymorphisms of the PAI-1 gene are known. The most frequently studied polymorphism with an outstanding importance regarding sepsis is the $-6754 \mathrm{G} / 5 \mathrm{G}$ insertion/ deletion polymorphism in the promoter region, affecting PAI-1 plasma levels and activity. ${ }^{91}$ It has been shown that presence of the $4 \mathrm{G} / 4 \mathrm{G}$ genotype results in elevated plasma levels and activity and increases susceptibility to sepsis and mortality in children with meningococcal infection, and also raises the incidence of DIC. ${ }^{92,93}$ Its further consequences include elevated risks of septic shock and MOF in pneumonia-induced sepsis. ${ }^{94}$ The significance of this genetic variant lies in the fact that the administration of tPA and APC is a therapeutic option that might improve outcomes. ${ }^{95-98}$

\section{Fibrinogen}

Fibrinogen, or factor I, is synthesized in the liver. As part of the coagulation cascade, it is converted into fibrin by thrombin. Of the polymorphisms of the fibrinogen- $\beta$ gene, research into $-854 \mathrm{G} / \mathrm{A},-455 \mathrm{G} / \mathrm{A}$, and $+9006 \mathrm{G} / \mathrm{A}$ revealed that even though the GAA haplotype causes elevated fibrinogen levels owing to the $-455 \mathrm{~A}$ allele, it reduces mortality and MOF incidence in sepsis. ${ }^{99-102}$ This might be explained by the fact that in addition to its role in coagulation, fibrinogen also takes part in the inflammatory process since it is a member of the acute phase proteins; it promotes neutrophil and IL-8 secretion as well as exerts an antiapoptotic effect on endothelial cells and neutrophils. ${ }^{103-107}$

\section{Effector Molecules}

\section{Fcy Receptors}

Fcy receptors earned their name by binding the Fc region of immunoglobulin $\mathrm{G}$ (IgG). They can also be found on many immune and nonimmune cell types. Their task is to stimulate phagocytes or cytotoxic cells, which destroy pathogens or infected host cells by antibody-mediated phagocytosis or through a mechanism referred to as antibody-dependent cell-mediated cytotoxicity. They have three subclasses, FcyRI (Fcyrla), FcyRII (a, b, c), and FcyRIII (a, b), each with a different level of affinity to various IgG antibodies. Several polymorphisms affecting receptor function have been described in these three groups. ${ }^{108}$ The most important polymorphism of the FcyRIIa gene results in an arginine-histidine switch at position 131 of the protein $(\mathrm{R} 131 \mathrm{H})$; the R131 allotype causes the receptor to bind the IgG2 molecule with a reduced affinity, which results in a slowdown of IgG2-opsonized phagocytosis. ${ }^{109-111}$ IgG2 is the major antibody subtype in the defense against encapsulated bacteria (e.g., Neisseria meningitidis); this mutation increases the susceptibility for these pathogen. ${ }^{109,112,113}$ The most significant polymorphism of FcyRIIIa causes a valine-phenylalanine switch at position 158 , which 
modifies the receptor's affinity to IgG1, IgG2, and IgG4. ${ }^{114,115}$ For FcyRIIIb, the polymorphism causes a switch in four amino acids (Na1/Na2), which affects the extracellular domain and has a role in protein glycosylation and hence the phagocytosis of particles opsonized by IgG1 and IgG3..$^{116-118}$ Phagocytosis is more efficient in FcyRIIIb Na1/Na1 homozygosity. Research into the polymorphisms FcyRII H131 and FcyRIIIa Na2 has revealed that both are associated with an increased susceptibility to meningococcal infection. ${ }^{119-124}$ Although the results are controversial, most studies confirm these findings.

\section{Other Molecules}

\section{Complement System}

The complement system is part of the innate immune system that enhances (complements) the functions of antibodies and phagocytic cells, thus helping to eliminate pathogens and remove damaged cells; on the other hand, it promotes inflammation and directly damages pathogen's membranes. ${ }^{125}$ Its activation may occur through three pathways: the classical, lectin, and the alternative pathways. ${ }^{126}$ It is important to note that the alternative pathway is constantly activated for antibacterial defense and that it also enhances the other two pathways. ${ }^{127}$ The regulatory role of complement factor $\mathrm{H}(\mathrm{CFH})$ is extremely important in preventing uncontrolled complement activation and excess damage. CFH levels gradually rise from as early on as the acute phase of inflammation. ${ }^{128}$ The effect of complement factor B is the exact opposite, that is, potentiating function of the alternative pathway. The classical and lectin pathways are activated by the $\mathrm{C} 1 \mathrm{q}$ protein and $\mathrm{MBL}$, respectively. Gene polymorphisms in components of the complement system affect normal functioning of the system. Such mutations most commonly affect CFH. By inhibiting CFH function, $\mathrm{CFH}$ $\mathrm{Y} 402 \mathrm{H}$ polymorphism has a protective effect because inhibition of the alternative pathway becomes muted and has a higher baseline level of activity. ${ }^{129}$ The CFH $-496 \mathrm{C} / \mathrm{T}$ CC genotype, accompanied by elevated $\mathrm{CFH}$ levels, is a factor of increased risk for meningococcal infection. ${ }^{130}$ MBL-2 polymorphisms increase the risk of sepsis. In summary, mutations that facilitate rapid and efficient activation of the complement system are protective against sepsis.

\section{Macrophage Migration Inhibitory Factor}

"Macrophage migration inhibitory factor" (MIF) is an important regulator of the innate immune system. ${ }^{131}$ It plays an important role in acute and chronic inflammatory processes and autoimmune diseases. In response to stimulatory effects of bacterial antigens, white blood cells produce MIF, ${ }^{132}$ which binds to CD74 molecules on the surfaces of other immunocytes, triggering the acute immune response. MIF is constantly expressed by macrophages and monocytes and has autocrine, paracrine, and endocrine effects when secreted into the extracellular space. Interestingly, glucocorticoids also induce MIF secretion, which, in turn, counters their anti-inflammatory effect. For note, the frontal hypophysis also produces MIF in response to trauma. ${ }^{133}$ There are four known polymorphisms to the MIF gene. The SNPs +254 $\left(+254^{*} \mathrm{~T} / \mathrm{C}\right)$ and $+656\left(+656^{*} \mathrm{C} / \mathrm{G}\right)$ are in the introns but bear no functional significance. ${ }^{134}$ This is in contrast with the other two polymorphisms situated in the promoter region. One of them is an SNP ( $-173 \mathrm{G} / \mathrm{C}$; rs755622), whereas the other is a microsatellite ( $\left.-794 \mathrm{CATT}_{5-8} ; \mathrm{rs}^{2} 844572\right)$. The most frequent allele in the Caucasian population is CATT6. Genotypes are classified into a so-called low-expression group with lower MIF levels (5-CATT allele or -173GG) and a high-expression group (7-CATT or the $-173 \mathrm{C}$ alleles). The $-173 \mathrm{G}$ allele is much more prevalent than the $C$ allele. Infectious disease studies have shown that high-expression MIF alleles (CATT7/8) or haplotypes are associated with severely complicated malaria, mortality of severely septic patients, and survival in community-acquired pneumonia. ${ }^{135,136}$ Also, the low-expression allele (CATT5) has a protective effect against meningococcal infection in children. ${ }^{137}$ This suggests that the effects of MIF polymorphisms are modified by age, infection site, pathogen type, and other confounding factors (e.g., selection bias). ${ }^{138-140}$ Another study has reported that although the haplotype $-173 \mathrm{C}$ /-794CATT7 is not useful as a susceptibility marker for sepsis, it may still help identify patients at increased risk of sepsis mortality. ${ }^{141}$ The practical significance of research into MIF polymorphisms lies in an ongoing phase $1 / 2$ a study for the efficacy assessment of an anti-MIF monoclonal antibody (BAX/imalumab) in patients with metastatic colorectal carcinoma or ovarian cancer with malignant ascites. ${ }^{134}$ Potential future use of the antibody might even include the treatment of severe sepsis.

\section{Heat Shock Proteins}

Heat shock proteins are members of a family of proteins produced in response to cells being exposed to stressful conditions. Some members of this family have "chaperone" function; they stabilize newly synthesized proteins, facilitate correct folding, and help damaged proteins to refold. ${ }^{142}$ As for the immune system, the most important heat shock protein is HSP70 located in the cell membrane because it plays a role in antigen binding and presentation to immunocytes. The gene encoding HSP70 is found in the HLA locus on the short arm of chromosome 6 . There are many known polymorphisms to the HSP70 gene, of which HSPA1A, HSPA1B, and HSPA1L have significance in relation to sepsis. Polymorphisms of the HSPA1B and HSPA1L genes modify the levels of selected cytokines and thus the process of SIRS. For example, the $A$ allele in HSPA1B 1538G/A, as well as the C allele in HSPA1L $2437 \mathrm{~T}>\mathrm{C}$, causes elevated TNF- $\alpha$ and IL- 6 levels, and the $\mathrm{C}$ allele is also a significant risk factor for liver failure and MOF. ${ }^{143}$ It has been reported that $1267 \mathrm{~A}>\mathrm{G}$ mutation in the HSPA1B gene increases the risk of sepsis in adults with community-acquired pneumonia. ${ }^{144,145}$ The A allele of rs1061581 and the rs1008438 mutation both cause hematological impairment, whereas the $C$ allele of rs1043618 leads to longer intensive care unit treatment periods in $\mathrm{H} 1 \mathrm{~N} 1$ infection and to a higher incidence of liver failure and MOF in severe trauma cases. ${ }^{144}$ Another study points out that AA (rs1061581) genotype of the HSPA1B gene is clearly associated with sepsis secondary to community-acquired pneumonia. ${ }^{145}$ 
This polymorphism is in a strong "linkage disequilibrium" with that of the promoter regions of HSPA1A and HSPA1B. ${ }^{146}$ Investigations into the HSP70-2A/G polymorphism found that the $G$ allele is associated with lower protein levels and represents an increased risk for sepsis. For the A allele, a link has been found with TNF-b2, which worsens outcomes in sepsis. ${ }^{146}$

\section{Dimethylarginine Dimethylaminohydrolase}

Dimethylarginine dimethylaminohydrolase (DDAH) metabolizes the asymmetric dimethylarginine (ADMA) molecule, which is an inhibitor of inducible nitric oxide synthase. ${ }^{147}$ The effects of NO include vasodilation, intense inflammatory response, and reduced thrombocyte and leukocyte adhesion, and it also has a free radical scavenger function. ADMA is synthesized from L-arginine by protein arginine methyltransferase. There is an association between ADMA levels and sepsis. ${ }^{148}$ The DDAH2 gene has two relatively known polymorphisms: $-8716 \mathrm{~g} / 7 \mathrm{~g}$ insertion/deletion and the SNP $-449 \mathrm{G} / \mathrm{C}^{148-151}$ The latter has a significance in sepsis since the $-449 \mathrm{G}$ allele has been shown to result in lower ADMA levels and is more likely to be present in sepsis accompanied by "cold shock." 152

\section{Discussion}

Changes to genes of sepsis mediators have an important role in the susceptibility to the severity and outcome of sepsis. Currently available choices in gene therapy are limited; nevertheless, options do exist and include antibody treatment against abnormally high levels of mediators produced by a mutation (e.g., monoclonal antibodies used against MIF), or potential administration of tPA or APC in genetic alterations of PAI-1. With the advance of molecular genetic methods, genetic testing, even screening, of patient groups at high risk of sepsis, for example, children with chronic diseases (leukemia etc.), may become reality in the future. This would offer a way to reduce the risk of sepsis onset by gene therapy in selected patients carrying mutations; in the interim until such therapy is available, stricter observation and more aggressive sepsis therapy could improve outcomes in these patients. This, however, necessitates further research to clarify in detail the sepsis-related roles of each polymorphism.

\section{References}

1 Wright SD, Ramos RA, Tobias PS, Ulevitch RJ, Mathison JC. CD14, a receptor for complexes of lipopolysaccharide (LPS) and LPS binding protein. Science 1990;249(4975):1431-1433

2 Fenton MJ, Golenbock DT. LPS-binding proteins and receptors. J Leukoc Biol 1998;64(01):25-32

3 Zeng L, Gu W, Zhang AQ, et al. A functional variant of lipopolysaccharide binding protein predisposes to sepsis and organ dysfunction in patients with major trauma. Ann Surg 2012; 255(01):147-157

4 Calafat J, Janssen H, Tool A, et al. The bactericidal/permeabilityincreasing protein (BPI) is present in specific granules of human eosinophils. Blood 1998;91(12):4770-4775
5 Mannion BA, Weiss J, Elsbach P. Separation of sublethal and lethal effects of the bactericidal/permeability increasing protein on Escherichia coli. J Clin Invest 1990;85(03): 853-860

6 Marra MN, Wilde CG, Griffith JE, Snable JL, Scott RW. Bactericidal/permeability-increasing protein has endotoxin-neutralizing activity. J Immunol 1990;144(02):662-666

7 Iovine NM, Elsbach P, Weiss J. An opsonic function of the neutrophil bactericidal/permeability-increasing protein depends on both its N- and C-terminal domains. Proc Natl Acad Sci U S A 1997;94(20):10973-10978

8 Hubacek JA, Büchler C, Aslanidis C, Schmitz G. The genomic organization of the genes for human lipopolysaccharide binding protein (LBP) and bactericidal permeability increasing protein (BPI) is highly conserved. Biochem Biophys Res Commun 1997; 236(02):427-430

9 Michalek J, Svetlikova P, Fedora M, et al. Bactericidal permeability increasing protein gene variants in children with sepsis. Intensive Care Med 2007;33(12):2158-2164

10 Kufer TA, Banks DJ, Philpott DJ. Innate immune sensing of microbes by Nod proteins. Ann N Y Acad Sci 2006;1072:19-27

11 Ogura $\mathrm{Y}$, Bonen DK, Inohara N, et al. A frameshift mutation in NOD2 associated with susceptibility to Crohn's disease. Nature 2001;411(6837):603-606

12 Tsujimoto H, Ono S, Efron PA, Scumpia PO, Moldawer LL, Mochizuki H. Role of Toll-like receptors in the development of sepsis. Shock 2008;29(03):315-321

13 Medzhitov R. Toll-like receptors and innate immunity. Nat Rev Immunol 2001;1(02):135-145

14 Seabury CM, Cargill EJ, Womack JE. Sequence variability and protein domain architectures for bovine Toll-like receptors 1,5 , and 10. Genomics 2007;90(04):502-515

15 Wurfel MM, Gordon AC, Holden TD, et al. Toll-like receptor 1 polymorphisms affect innate immune responses and outcomes in sepsis. Am J Respir Crit Care Med 2008;178(07):710-720

16 Johnson CM, Lyle EA, Omueti KO, et al. Cutting edge: a common polymorphism impairs cell surface trafficking and functional responses of TLR1 but protects against leprosy. J Immunol 2007; 178(12):7520-7524

17 Whitmore LC, Hook JS, Philiph AR, et al. A Common genetic variant in TLR1 enhances human neutrophil priming and impacts length of intensive care stay in pediatric sepsis. J Immunol 2016;196(03):1376-1386

18 Smith MF Jr, Mitchell A, Li G, et al. Toll-like receptor (TLR) 2 and TLR5, but not TLR4, are required for Helicobacter pylori-induced NF-K B activation and chemokine expression by epithelial cells. J Biol Chem 2003;278(35):32552-32560

19 Xiong Y, Song C, Snyder GA, Sundberg EJ, Medvedev AE. R753Q polymorphism inhibits Toll-like receptor (TLR) 2 tyrosine phosphorylation, dimerization with TLR6, and recruitment of myeloid differentiation primary response protein 88 . J Biol Chem 2012;287(45):38327-38337

20 Lorenz E, Mira JP, Cornish KL, Arbour NC, Schwartz DA. A novel polymorphism in the toll-like receptor 2 gene and its potential association with staphylococcal infection. Infect Immun 2000;68 (11):6398-6401

21 Gao JW, Zhang AQ, Wang X, et al. Association between the TLR2 Arg753Gln polymorphism and the risk of sepsis: a meta-analysis. Crit Care 2015;19:416. Doi: 10.1186/s13054-015-1130-3

22 Lorenz E, Mira JP, Frees KL, Schwartz DA. Relevance of mutations in the TLR4 receptor in patients with gram-negative septic shock. Arch Intern Med 2002;162(09):1028-1032

23 Jessen KM, Lindboe SB, Petersen AL, Eugen-Olsen J, Benfield T. Common TNF-alpha, IL-1 beta, PAI-1, uPA, CD14 and TLR4 polymorphisms are not associated with disease severity or outcome from Gram negative sepsis. BMC Infect Dis 2007;7:108. Doi: $10.1186 / 1471-2334-7-108$ 
24 Ferwerda B, McCall MB, Alonso S, et al. TLR4 polymorphisms, infectious diseases, and evolutionary pressure during migration of modern humans. Proc Natl Acad Sci U S A 2007;104(42): $16645-16650$

25 Ferwerda B, McCall MB, Verheijen K, et al. Functional consequences of toll-like receptor 4 polymorphisms. Mol Med 2008; 14(5-6):346-352

26 Chantratita N, Tandhavanant S, Seal S, et al. TLR4 genetic variation is associated with inflammatory responses in Gram-positive sepsis. Clin Microbiol Infect 2017;23(01):47.e1-47.e10

27 Mansur A, von Gruben L, Popov AF, et al. The regulatory toll-like receptor 4 genetic polymorphism rs11536889 is associated with renal, coagulation and hepatic organ failure in sepsis patients. J Transl Med 2014;12:177. Doi: 10.1186/1479-5876-12-177

28 Lin J, Yao YM, Yu Y, et al. Effects of CD14-159 C/T polymorphism on CD14 expression and the balance between proinflammatory and anti-inflammatory cytokines in whole blood culture. Shock 2007;28(02):148-153

29 Burgmann $\mathrm{H}$, Winkler S, Locker GJ, et al. Increased serum concentration of soluble CD14 is a prognostic marker in grampositive sepsis. Clin Immunol Immunopathol 1996;80(3 Pt 1):307-310

30 Landmann R, Zimmerli W, Sansano S, et al. Increased circulating soluble CD14 is associated with high mortality in gram-negative septic shock. J Infect Dis 1995;171(03):639-644

$31 \mathrm{Gu} \mathrm{W}$, Dong H, Jiang DP, et al. Functional significance of CD14 promoter polymorphisms and their clinical relevance in a Chinese Han population. Crit Care Med 2008;36(08):2274-2280

32 Zhang $\mathrm{AQ}$, Yue $\mathrm{CL}, \mathrm{Gu}$ W, Du J, Wang HY, Jiang J. Association between CD14 promoter -159C/T polymorphism and the risk of sepsis and mortality: a systematic review and metaanalysis. PLoS One 2013;8(08):e71237. Doi: 10.1371/journal. pone.0071237

33 Turner MW. Mannose-binding lectin: the pluripotent molecule of the innate immune system. Immunol Today 1996;17(11): $532-540$

34 Steffensen R, Thiel S, Varming K, Jersild C, Jensenius JC. Detection of structural gene mutations and promoter polymorphisms in the mannan-binding lectin (MBL) gene by polymerase chain reaction with sequence-specific primers. J Immunol Methods 2000;241(1-2):33-42

35 Madsen HO, Garred P, Thiel S, et al. Interplay between promoter and structural gene variants control basal serum level of mannan-binding protein. J Immunol 1995;155(06):3013-3020

36 Hibberd ML, Sumiya M, Summerfield JA, Booy R, Levin M; Meningococcal Research Group. Association of variants of the gene for mannose-binding lectin with susceptibility to meningococcal disease. Lancet 1999;353(9158):1049-1053

37 Summerfield JA, Sumiya M, Levin M, Turner MW. Association of mutations in mannose binding protein gene with childhood infection in consecutive hospital series. BMJ 1997;314 (7089):1229-1232

38 Lawrence T. The nuclear factor NF-kappaB pathway in inflammation. Cold Spring Harb Perspect Biol 2009;1(06):a001651. Doi: 10.1101/cshperspect.a001651

39 Toubiana J, Courtine E, Tores F, et al. Association of REL polymorphisms and outcome of patients with septic shock. Ann Intensive Care 2016;6(01):28. Doi: 10.1186/s13613-016-0130-z

40 Gordon AC, Lagan AL, Aganna E, et al. TNF and TNFR polymorphisms in severe sepsis and septic shock: a prospective multicentre study. Genes Immun 2004;5(08):631-640

41 Dahmer MK, Randolph A, Vitali S, Quasney MW. Genetic polymorphisms in sepsis. Pediatr Crit Care Med 2005;6(3, Suppl): S61-S73

42 Wilson AG, de Vries N, Pociot F, di Giovine FS, van der Putte LB, Duff GW. An allelic polymorphism within the human tumor necrosis factor alpha promoter region is strongly associated with HLA A1, B8, and DR3 alleles. J Exp Med 1993;177(02):557-560
43 Wilson AG, Symons JA, McDowell TL, McDevitt HO, Duff GW. Effects of a polymorphism in the human tumor necrosis factor alpha promoter on transcriptional activation. Proc Natl Acad Sci U S A 1997;94(07):3195-3199

44 Teuffel O, Ethier MC, Beyene J, Sung L. Association between tumor necrosis factor-alpha promoter $-308 \mathrm{~A} / \mathrm{G}$ polymorphism and susceptibility to sepsis and sepsis mortality: a systematic review and meta-analysis. Crit Care Med 2010;38(01):276-282

45 Kaluza W, Reuss E, Grossmann S, et al. Different transcriptional activity and in vitro TNF-alpha production in psoriasis patients carrying the TNF-alpha 238A promoter polymorphism. J Invest Dermatol 2000;114(06):1180-1183

46 McArthur JA, Zhang Q Quasney MW. Association between the A/A genotype at the lymphotoxin-alpha +250 site and increased mortality in children with positive blood cultures. Pediatr Crit Care Med 2002;3(04):341-344

47 Kurt AN, Aygun AD, Godekmerdan A, Kurt A, Dogan Y, Yilmaz E. Serum IL-1beta, IL-6, IL-8, and TNF-alpha levels in early diagnosis and management of neonatal sepsis. Mediators Inflamm 2007;2007:31397

48 Fida NM, Al-Mughales J, Farouq M. Interleukin-1alpha, interleukin-6 and tumor necrosis factor-alpha levels in children with sepsis and meningitis. Pediatr Int 2006;48(02):118-124

49 Pruitt JH, Copeland EM III, Moldawer LL. Interleukin-1 and interleukin-1 antagonism in sepsis, systemic inflammatory response syndrome, and septic shock. Shock 1995;3(04):235-251

50 Dinarello CA. Biologic basis for interleukin-1 in disease. Blood 1996;87(06):2095-2147

51 Zhang AQ Pan W, Gao JW, et al. Associations between interleukin-1 gene polymorphisms and sepsis risk: a meta-analysis. BMC Med Genet 2014;15:8. Doi: 10.1155/2007/31397

52 Shirodaria S, Smith J, McKay IJ, Kennett CN, Hughes FJ. Polymorphisms in the IL-1A gene are correlated with levels of interleukin-1alpha protein in gingival crevicular fluid of teeth with severe periodontal disease. J Dent Res 2000;79(11): 1864-1869

53 Pociot F, Mølvig J, Wogensen L, Worsaae H, Nerup J. A TaqI polymorphism in the human interleukin-1 beta (IL-1 beta) gene correlates with IL-1 beta secretion in vitro. Eur J Clin Invest 1992; 22(06):396-402

54 Hack CE, De Groot ER, Felt-Bersma RJ, et al. Increased plasma levels of interleukin-6 in sepsis. Blood 1989;74(05):1704-1710

55 Waage A, Brandtzaeg P, Halstensen A, Kierulf P, Espevik T. The complex pattern of cytokines in serum from patients with meningococcal septic shock. Association between interleukin 6, interleukin 1, and fatal outcome. J Exp Med 1989;169(01): 333-338

56 Fishman D, Faulds G, Jeffery R, et al. The effect of novel polymorphisms in the interleukin-6 (IL-6) gene on IL-6 transcription and plasma IL-6 levels, and an association with systemic-onset juvenile chronic arthritis. J Clin Invest 1998;102(07):1369-1376

57 Kilpinen S, Hulkkonen J, Wang XY, Hurme M. The promoter polymorphism of the interleukin-6 gene regulates interleukin-6 production in neonates but not in adults. Eur Cytokine Netw 2001;12(01):62-68

58 Haddy N, Sass C, Maumus S, et al. Biological variations, genetic polymorphisms and familial resemblance of TNF-alpha and IL-6 concentrations: STANISLAS cohort. Eur J Hum Genet 2005;13 (01):109-117

59 Bennermo M, Held C, Stemme S, et al. Genetic predisposition of the interleukin- 6 response to inflammation: implications for a variety of major diseases? Clin Chem 2004;50(11):2136-2140

60 Schlüter B, Raufhake C, Erren M, et al. Effect of the interleukin-6 promoter polymorphism $(-174 \mathrm{G} / \mathrm{C})$ on the incidence and outcome of sepsis. Crit Care Med 2002;30(01):32-37

61 Michalek J, Svetlikova P, Fedora M, et al. Interleukin-6 gene variants and the risk of sepsis development in children. Hum Immunol 2007;68(09):756-760 
62 Sutherland AM, Walley KR, Manocha S, Russell JA. The association of interleukin 6 haplotype clades with mortality in critically ill adults. Arch Intern Med 2005;165(01):75-82

63 Miyoshi T, Yamashita K, Arai T, Yamamoto K, Mizugishi K, Uchiyama T. The role of endothelial interleukin-8/NADPH oxidase 1 axis in sepsis. Immunology 2010;131(03):331-339

64 Mera S, Tatulescu D, Cismaru C, et al. Multiplex cytokine profiling in patients with sepsis. APMIS 2011;119(02):155-163

65 Esposito S, Zampiero A, Pugni L, et al. Genetic polymorphisms and sepsis in premature neonates. PLoS One 2014;9(07): e101248. Doi: 10.1371/journal.pone.0101248

66 Hillian AD, Londono D, Dunn JM, et al; CF Gene Modifier Study Group. Modulation of cystic fibrosis lung disease by variants in interleukin-8. Genes Immun 2008;9(06):501-508

67 Wacharasint P, Nakada TA, Boyd JH, Russell JA, Walley KR. AA genotype of IL-8 $-251 \mathrm{~A} / \mathrm{T}$ is associated with low $\mathrm{PaO}(2) / \mathrm{FiO}(2)$ in critically ill patients and with increased IL-8 expression. Respirology 2012;17(08):1253-1260

68 Hull J, Thomson A, Kwiatkowski D. Association of respiratory syncytial virus bronchiolitis with the interleukin 8 gene region in UK families. Thorax 2000;55(12):1023-1027

$69 \mathrm{Hu} \mathrm{D}$, Wang $\mathrm{H}$, Huang $\mathrm{X}$, et al. Investigation of association between IL-8 serum levels and IL8 polymorphisms in Chinese patients with sepsis. Gene 2016;594(01):165-170

70 Schoenborn JR, Wilson CB. Regulation of interferon-gamma during innate and adaptive immune responses. Adv Immunol 2007;96:41-101

71 Wang D, Zhong X, Huang D, et al. Functional polymorphisms of interferon-gamma affect pneumonia-induced sepsis. PLoS One 2014;9(01):e87049. Doi: 10.1371/journal.pone.0087049

72 Wang H, Bloom O, Zhang M, et al. HMG-1 as a late mediator of endotoxin lethality in mice. Science 1999;285(5425):248-251

73 Scaffidi P, Misteli T, Bianchi ME. Release of chromatin protein HMGB1 by necrotic cells triggers inflammation. Nature 2002; 418(6894):191-195

74 Palumbo R, Bianchi ME. High mobility group box 1 protein, a cue for stem cell recruitment. Biochem Pharmacol 2004;68(06): $1165-1170$

75 Kornblit B, Munthe-Fog L, Madsen HO, Strøm J, Vindeløv L, Garred P. Association of HMGB1 polymorphisms with outcome in patients with systemic inflammatory response syndrome. Crit Care 2008;12(03):R83. Doi: 10.1186/cc6935

76 Lee K, Chang Y, Song K, et al. Associations between Single Nucleotide Polymorphisms of High Mobility Group Box 1 Protein and Clinical Outcomes in Korean Sepsis Patients. Yonsei Med J 2016;57(01):111-117

77 Vamvakopoulos JE, Taylor CJ, Morris-Stiff GJ, Green C, Metcalfe S. The interleukin-1 receptor antagonist gene: a single-copy variant of the intron 2 variable number tandem repeat (VNTR) polymorphism. Eur J Immunogenet 2002;29(04):337-340

78 Witkin SS, Gerber S, Ledger WJ. Influence of interleukin-1 receptor antagonist gene polymorphism on disease. Clin Infect Dis 2002;34(02):204-209

79 Lim WY, Chen Y, Ali SM, et al. Polymorphisms in inflammatory pathway genes, host factors and lung cancer risk in Chinese female never-smokers. Carcinogenesis 2011;32(04):522-529

80 Arnalich F, López-Maderuelo D, Codoceo R, et al. Interleukin-1 receptor antagonist gene polymorphism and mortality in patients with severe sepsis. Clin Exp Immunol 2002;127(02): 331-336

81 Zanotti S, Kumar A, Kumar A. Cytokine modulation in sepsis and septic shock. Expert Opin Investig Drugs 2002;11(08): 1061-1075

82 Gibson AW, Edberg JC, Wu J, Westendorp RG, Huizinga TW, Kimberly RP. Novel single nucleotide polymorphisms in the distal IL-10 promoter affect IL-10 production and enhance the risk of systemic lupus erythematosus. J Immunol 2001;166(06): 3915-3922
83 Stanilova SA, Miteva LD, Karakolev ZT, Stefanov CS. Interleukin10-1082 promoter polymorphism in association with cytokine production and sepsis susceptibility. Intensive Care Med 2006; 32:260-266

84 Shu Q, Fang X, Chen Q Stuber F. IL-10 polymorphism is associated with increased incidence of severe sepsis. Chin Med J (Engl) 2003;116(11):1756-1759

85 Mosnier LO, Zlokovic BV, Griffin JH. The cytoprotective protein C pathway. Blood 2007;109(08):3161-3172

86 Scopes D, Berg LP, Krawczak M, Kakkar VV, Cooper DN. Polymorphic variation in the human protein $\mathrm{C}$ ( $\mathrm{PROC}$ ) gene promoter can influence transcriptional efficiency in vitro. Blood Coagul Fibrinolysis 1995;6(04):317-321

87 Spek CA, Greengard JS, Griffin JH, Bertina RM, Reitsma PH. Two mutations in the promoter region of the human protein $C$ gene both cause type I protein C deficiency by disruption of two HNF3 binding sites. J Biol Chem 1995a270(41):24216-24221

88 Annane D, Bellissant E, Cavaillon JM. Septic shock. Lancet 2005; 365(9453):63-78

89 Binder A, Endler G, Rieger S, et al; Central European Meningococcal Genetic Study Group. Protein C promoter polymorphisms associate with sepsis in children with systemic meningococcemia. Hum Genet 2007;122(02):183-190

90 Walley KR, Russell JA. Protein C -1641 AA is associated with decreased survival and more organ dysfunction in severe sepsis. Crit Care Med 2007;35(01):12-17

91 Eriksson P, Kallin B, van 't Hooft FM, Båvenholm P, Hamsten A. Allele-specific increase in basal transcription of the plasminogen-activator inhibitor 1 gene is associated with myocardial infarction. Proc Natl Acad Sci U S A 1995;92(06):1851-1855

92 Hermans PW, Hibberd ML, Booy R, et al; Meningococcal Research Group. 4G/5G promoter polymorphism in the plasminogenactivator-inhibitor- 1 gene and outcome of meningococcal disease. Lancet 1999;354(9178):556-560

93 Binder A, Endler G, Müller M, Mannhalter C, Zenz W; European Meningococcal Study Group. 4G4G genotype of the plasminogen activator inhibitor-1 promoter polymorphism associates with disseminated intravascular coagulation in children with systemic meningococcemia. J Thromb Haemost 2007;5(10):2049-2054

94 Madách K, Aladzsity I, Szilágyi A, et al. 4G/5G polymorphism of PAI-1 gene is associated with multiple organ dysfunction and septic shock in pneumonia induced severe sepsis: prospective, observational, genetic study. Crit Care 2010;14(02):R79. Doi: $10.1186 / \mathrm{cc} 8992$

95 Zenz W, Zoehrer B, Levin M, et al; International Paediatric Meningococcal Thrombolysis Study Group. Use of recombinant tissue plasminogen activator in children with meningococcal purpura fulminans: a retrospective study. Crit Care Med 2004;32 (08):1777-1780

96 Zenz W, Muntean W, Zobel G, Grubbauer HM, Gallistl S. Treatment of fulminant meningococcemia with recombinant tissue plasminogen activator. Thromb Haemost 1995;74(02):802-803

97 Bernard GR, Vincent JL, Laterre PF, et al; Recombinant human protein C Worldwide Evaluation in Severe Sepsis (PROWESS) study group. Efficacy and safety of recombinant human activated protein C for severe sepsis. N Engl J Med 2001;344(10):699-709

98 Sakata Y, Loskutoff DJ, Gladson CL, Hekman CM, Griffin JH. Mechanism of protein C-dependent clot lysis: role of plasminogen activator inhibitor. Blood 1986;68(06):1218-1223

99 Green FR. Fibrinogen polymorphisms and atherothrombotic disease. Ann N Y Acad Sci 2001;936:549-559

100 Brull DJ, Dhamrait S, Moulding R, et al. The effect of fibrinogen genotype on fibrinogen levels after strenuous physical exercise. Thromb Haemost 2002;87(01):37-41

101 Iso H, Folsom AR, Winkelmann JC, et al. Polymorphisms of the beta fibrinogen gene and plasma fibrinogen concentration in Caucasian and Japanese population samples. Thromb Haemost 1995;73(01):106-111 
102 van't Hooft FM, von Bahr SJ, Silveira A, Iliadou A, Eriksson P, Hamsten A. Two common, functional polymorphisms in the promoter region of the beta-fibrinogen gene contribute to regulation of plasma fibrinogen concentration. Arterioscler Thromb Vasc Biol 1999;19(12):3063-3070

103 Skogen WF, Senior RM, Griffin GL, Wilner GD. Fibrinogenderived peptide B beta $1-42$ is a multidomained neutrophil chemoattractant. Blood 1988;71(05):1475-1479

104 Leavell KJ, Peterson MW, Gross TJ. The role of fibrin degradation products in neutrophil recruitment to the lung. Am J Respir Cell Mol Biol 1996;14(01):53-60

105 Kuhns DB, Nelson EL, Alvord WG, Gallin JI. Fibrinogen induces IL8 synthesis in human neutrophils stimulated with formylmethionyl-leucyl-phenylalanine or leukotriene B(4). J Immunol 2001;167(05):2869-2878

106 Rubel C, Fernández GC, Dran G, Bompadre MB, Isturiz MA, Palermo MS. Fibrinogen promotes neutrophil activation and delays apoptosis. J Immunol 2001;166(03):2002-2010

107 Rubel C, Gómez S, Fernández GC, Isturiz MA, Caamaño J, Palermo MS. Fibrinogen-CD11b/CD18 interaction activates the NF-kappa B pathway and delays apoptosis in human neutrophils. Eur J Immunol 2003;33(05):1429-1438

108 van Sorge NM, van der Pol WL, van de Winkel JG. FcgammaR polymorphisms: implications for function, disease susceptibility and immunotherapy. Tissue Antigens 2003:61(03):189-202

109 Warmerdam PA, van de Winkel JG, Vlug A, Westerdaal NA, Capel PJ. A single amino acid in the second Ig-like domain of the human Fc gamma receptor II is critical for human IgG2 binding. J Immunol 1991;147(04):1338-1343

110 Salmon JE, Edberg JC, Brogle NL, Kimberly RP. Allelic polymorphisms of human Fc gamma receptor IIA and Fc gamma receptor IIIB. Independent mechanisms for differences in human phagocyte function. J Clin Invest 1992;89(04):1274-1281

111 Sanders LA, Feldman RG, Voorhorst-Ogink MM, et al. Human immunoglobulin $\mathrm{G}$ ( $\operatorname{IgG}$ ) Fc receptor IIA (CD32) polymorphism and IgG2-mediated bacterial phagocytosis by neutrophils. Infect Immun 1995;63(01):73-81

112 Herman DJ, Hamilton RG, Barington T, et al. Quantitation of human IgG subclass antibodies to Haemophilus influenzae type b capsular polysaccharide. Results of an international collaborative study using enzyme immunoassay methodology. J Immunol Methods 1992;148:101-114

113 Siber GR, Schur PH, Aisenberg AC, Weitzman SA, Schiffman G. Correlation between serum IgG-2 concentrations and the antibody response to bacterial polysaccharide antigens. N Engl J Med 1980;303(04):178-182

114 Wu J, Edberg JC, Redecha PB, et al. A novel polymorphism of FcgammaRIIIa (CD16) alters receptor function and predisposes to autoimmune disease. J Clin Invest 1997;100(05):1059-1070

115 Koene HR, Kleijer M, Algra J, Roos D, von dem Borne AE, de Haas M. FC gammaRIIIa-158V/F polymorphism influences the binding of IgG by natural killer cell Fc gammaRIIIa, independently of the Fc gammaRIIIa-48L/R/H phenotype. Blood 1997;90(03):1109-1114

116 Huizinga TW, Kleijer M, Tetteroo PA, Roos D, von dem Borne AE. Biallelic neutrophil Na-antigen system is associated with a polymorphism on the phospho-inositol-linked Fc gamma receptor III (CD16). Blood 1990;75(01):213-217

117 Salmon JE, Edberg JC, Kimberly RP. Fc gamma receptor III on human neutrophils. Allelic variants have functionally distinct capacities. J Clin Invest 1990;85(04):1287-1295

118 Salmon JE, Millard SS, Brogle NL, Kimberly RP. Fc gamma receptor IIIb enhances Fc gamma receptor Ila function in an oxidantdependent and allele-sensitive manner. J Clin Invest 1995; 95(06):2877-2885

119 Fijen CA, Bredius RG, Kuijper EJ. Polymorphism of IgG Fc receptors in meningococcal disease. Ann Intern Med 1993; 119(7 Pt 1):636
120 Bredius RG, Derkx BH, Fijen CA, et al. Fc gamma receptor IIa (CD32) polymorphism in fulminant meningococcal septic shock in children. J Infect Dis 1994;170(04):848-853

121 Platonov AE, Shipulin GA, Vershinina IV, Dankert J, van de Winkel JG, Kuijper EJ. Association of human Fc gamma RIIa (CD32) polymorphism with susceptibility to and severity of meningococcal disease. Clin Infect Dis 1998;27(04):746-750

122 Platonov AE, Kuijper EJ, Vershinina IV, et al. Meningococcal disease and polymorphism of FcgammaRIIa (CD32) in late complement component-deficient individuals. Clin Exp Immunol 1998;111(01):97-101

123 Domingo P, Muñiz-Diaz E, Baraldès MA, et al. Associations between Fc gamma receptor IIA polymorphisms and the risk and prognosis of meningococcal disease. Am J Med 2002; 112(01):19-25

124 van der Pol WL, Huizinga TW, Vidarsson G, et al. Relevance of Fcgamma receptor and interleukin-10 polymorphisms for meningococcal disease. J Infect Dis 2001;184(12):1548-1555

125 Janeway CA. The complement system and innate immunity. In: Immunobiology: The Immune System in Health and Disease. Janeway CA, Travers P, Walport M, Schlomchik M, eds. New York, NY: Garland Science; 2001

126 Abbas AK, Lichtman AH, Pillai S. Cellular and Molecular Immunology. 6th ed. Philadelphia, PA: Elsevier; 2010:272-288

127 Holers VM. The spectrum of complement alternative pathwaymediated diseases. Immunol Rev 2008;223:300-316

128 Rodríguez de Córdoba S, Esparza-Gordillo J, Goicoechea de Jorge E, Lopez-Trascasa M, Sánchez-Corral P. The human complement factor $\mathrm{H}$ : functional roles, genetic variations and disease associations. Mol Immunol 2004;41(04):355-367

129 Agbeko RS, Fidler KJ, Allen ML, Wilson P, Klein NJ, Peters MJ. Genetic variability in complement activation modulates the systemic inflammatory response syndrome in children. Pediatr Crit Care Med 2010;11(05):561-567

130 Haralambous E, Dolly SO, Hibberd ML, et al. Factor H, a regulator of complement activity, is a major determinant of meningococcal disease susceptibility in UK Caucasian patients. Scand J Infect Dis 2006;38(09):764-771

131 Calandra T, Roger T. Macrophage migration inhibitory factor: a regulator of innate immunity. Nat Rev Immunol 2003;3(10): 791-800

132 Barret J. Basic Immunology and its Medical Application. 2nd ed. St. Louis, MO: C.V. Mosby; 1980

133 Larson DF, Horak K. Macrophage migration inhibitory factor: controller of systemic inflammation. Crit Care 2006;10(02):138. Doi: $10.1186 /$ cc4899

134 Savva A, Brouwer MC, Roger T, et al. Functional polymorphisms of macrophage migration inhibitory factor as predictors of morbidity and mortality of pneumococcal meningitis. Proc Natl Acad Sci U S A 2016;113(13):3597-3602

135 Lehmann LE, Book M, Hartmann W, et al. A MIF haplotype is associated with the outcome of patients with severe sepsis: a case control study. J Transl Med 2009;7:100

136 Yende S, Angus DC, Kong L, et al. The influence of macrophage migration inhibitory factor gene polymorphisms on outcome from community-acquired pneumonia. FASEB J 2009;23(08): 2403-2411

137 Renner P, Roger T, Bochud PY, et al. A functional microsatellite of the macrophage migration inhibitory factor gene associated with meningococcal disease. FASEB J 2012;26(02):907-916

138 Brouwer MC, de Gans J, Heckenberg SG, Zwinderman AH, van der Poll T, van de Beek D. Host genetic susceptibility to pneumococcal and meningococcal disease: a systematic review and meta-analysis. Lancet Infect Dis 2009;9(01):31-44

139 Bochud PY, Bochud M, Telenti A, Calandra T. Innate immunogenetics: a tool for exploring new frontiers of host defence. Lancet Infect Dis 2007;7(08):531-542 
140 Chapman SJ, Hill AV. Human genetic susceptibility to infectious disease. Nat Rev Genet 2012;13(03):175-188

141 Lehmann LE, Book M, Hartmann W, et al. A MIF haplotype is associated with the outcome of patients with severe sepsis: a case control study. J Transl Med 2009;7:100. Doi: 10.1186/14795876-7-100

142 De Maio A. Heat shock proteins: facts, thoughts, and dreams. Shock 1999;11(01):1-12

143 Schröder O, Schulte KM, Ostermann P, Röher HD, Ekkernkamp A, Laun RA. Heat shock protein 70 genotypes HSPA1B and HSPA1L influence cytokine concentrations and interfere with outcome after major injury. Crit Care Med 2003;31(01):73-79

144 Waterer GW, ElBahlawan L, Quasney MW, Zhang Q, Kessler LA, Wunderink RG. Heat shock protein 70-2+1267 AA homozygotes have an increased risk of septic shock in adults with communityacquired pneumonia. Crit Care Med 2003;31(05):1367-1372

145 Temple SE, Cheong KY, Ardlie KG, Sayer D, Waterer GW. The septic shock associated HSPA1B1267 polymorphism influences production of HSPA1A and HSPA1B. Intensive Care Med 2004;30 (09):1761-1767

146 Schroeder S, Reck M, Hoeft A, Stüber F. Analysis of two human leukocyte antigen-linked polymorphic heat shock protein 70 genes in patients with severe sepsis. Crit Care Med 1999;27(07): $1265-1270$
147 Tran CT, Leiper JM, Vallance P. The DDAH/ADMA/NOS pathway. Atheroscler Suppl 2003;4(04):33-40

148 O’Dwyer MJ, Dempsey F, Crowley V, Kelleher DP, McManus R, Ryan T. Septic shock is correlated with asymmetrical dimethyl arginine levels, which may be influenced by a polymorphism in the dimethylarginine dimethylaminohydrolase II gene: a prospective observational study. Crit Care 2006;10(05):R139. Doi: $10.1186 /$ cc5053

149 Ryan R, Thornton J, Duggan E, et al. Gene polymorphism and requirement for vasopressor infusion after cardiac surgery. Ann Thorac Surg 2006;82(03):895-901

150 Bai Y, Chen J, Sun K, Xin Y, Liu J, Hui R. Common genetic variation in DDAH2 is associated with intracerebral haemorrhage in a Chinese population: a multi-centre case-control study in China. Clin Sci (Lond) 2009;117(07):273-279

151 Maas R, Erdmann J, Lüneburg N, et al. Polymorphisms in the promoter region of the dimethylarginine dimethylaminohydrolase 2 gene are associated with prevalence of hypertension. Pharmacol Res 2009;60(06):488-493

152 Weiss SL, Yu M, Jennings L, Haymond S, Zhang G, Wainwright MS Pilot study of the association of the DDAH2 -449G polymorphism with asymmetric dimethylarginine and hemodynamic shock in pediatric sepsis. PLoS One 2012;7(03):e33355. Doi: 10.1371/ journal.pone.0033355 